\title{
Kangiella taiwanensis sp. nov. and Kangiella marina sp. nov., marine bacteria isolated from shallow coastal water
}

\author{
Wen Dar Jean, ${ }^{1}$ Ssu-Po Huang, ${ }^{1}$ Jwo-Sheng Chen ${ }^{2}$ \\ and Wung Yang Shieh ${ }^{1}$ \\ ${ }^{1}$ Institute of Oceanography, National Taiwan University, PO Box 23-13, Taipei, Taiwan, ROC \\ ${ }^{2}$ College of Health Care, China Medical University, No. 91, Shyue-Shyh Rd, Taichung, Taiwan, ROC
}

Correspondence

Wung Yang Shieh

winyang@ntu.edu.tw

\begin{abstract}
Two Gram-negative, heterotrophic, aerobic, marine bacteria, designated strains $\mathrm{KT}^{\top}{ }^{\top}$ and $\mathrm{KM} 1^{\top}$, were isolated from seawater samples collected from the shallow coastal regions of northern Taiwan. Cells grown in broth cultures were non-flagellated rods. $\mathrm{NaCl}$ was required for growth. Optimal growth occurred with $2-5 \% \mathrm{NaCl}$, at $25-30{ }^{\circ} \mathrm{C}$ and at $\mathrm{pH}$. They grew aerobically and were not capable of anaerobic growth by fermenting D-glucose or other carbohydrates. Q-8 was the only isoprenoid quinone. The major polar lipid detected in strain $\mathrm{KT} 1^{\top}$ was phosphatidylmonomethylethanolamine, whereas those detected in $\mathrm{KM} 1^{\top}$ were phosphatidylmonomethylethanolamine, phosphatidyldimethylethanolamine and an unidentified phospholipid. Cellular fatty acids were nearly all iso-branched, with iso- $\mathrm{C}_{15: 0}$ as the most abundant component (54.6-57.2\% of the total). Strains $\mathrm{KT}^{\top}{ }^{\top}$ and $\mathrm{KM} 1^{\top}$ had DNA G+C contents of 43.9 and 46.3 mol\%, respectively. The two strains shared $98.1 \% 16 \mathrm{~S}$ rRNA gene sequence similarity; levels of similarity with the type strains of species of the genus Kangiella were 95.6-98.4\%. Data from the present taxonomic study conducted using a polyphasic approach revealed that the isolates could be classified as representatives of two novel species of the genus Kangiella, for which the names Kangiella taiwanensis sp. nov. (type strain $\mathrm{KT} 1^{\top}=\mathrm{BCRC}$ $80330^{\top}=\mathrm{JCM} 17727^{\top}$ ) and Kangiella marina sp. nov. (type strain $\mathrm{KM} 1^{\top}=\mathrm{BCRC} 80329^{\top}=\mathrm{JCM}$ $17728^{\top}$ ) are proposed.
\end{abstract}

The genus Kangiella, of the class Gammaproteobacteria, comprises marine, heterotrophic, Gram-negative rods that are non-motile and non-fermentative. The genus was originally established to accommodate two species, Kangiella koreensis (the type species) and Kangiella aquimarina (Yoon et al., 2004). These species were recovered from tidal flat sediment of Daepo Beach, Yellow Sea, Korea (Yoon et al., 2004). Three additional species have been described more recently: Kangiella japonica isolated from coastal seawater and sediment samples of the Sea of Japan, Russia (Romanenko et al., 2010), Kangiella spongicola isolated from a marine sponge sample collected from the Florida Keys, Florida, USA (Ahn et al., 2011) and Kangiella geojedonensis isolated from seawater of the South Sea, Korea (Yoon et al., 2012). Species of the genus Kangiella are unusual in possessing a rather high content of isobranched cellular fatty acids ( $>90 \%$ of the total).

The GenBank/EMBL/DDBJ accession numbers for the 16S rRNA gene sequences of strains $\mathrm{KT}^{\top}{ }^{\top}$ and $\mathrm{KM} 1^{\top}$ are JN559389 and JN559388, respectively.

A supplementary figure is available with the online version of this paper.
Two bacterial strains, designated $\mathrm{KT}^{\mathrm{T}}$ and $\mathrm{KM} 1^{\mathrm{T}}$, were isolated from seawater samples collected in the shallow coastal regions of Bangbang and Shenao, respectively; the two sampling sites are located on the north coast of Taiwan. Data from the present taxonomic study conducted using a polyphasic approach support the establishment of two novel species of the genus Kangiella with $\mathrm{KT}^{\mathrm{T}}$ and $\mathrm{KM}^{\mathrm{T}}$ as the type strains.

Seawater samples were diluted 10 -fold with sterile $\mathrm{NaCl} /$ Tris buffer $(30 \mathrm{~g} \mathrm{NaCl}$ and $0.24 \mathrm{~g}$ Tris base in 1 litre deionized water, $\mathrm{pH} 8.0)$. Aliquots $(0.1 \mathrm{ml})$ of the decimally diluted samples $\left(10^{-1}\right.$ to $\left.10^{-3}\right)$ were spread on polypeptone-yeast (PY) plate medium (Shieh et al., 2000) in triplicate. The plates were incubated at $30{ }^{\circ} \mathrm{C}$ in the dark for 7 days under aerobic conditions. Individual colonies appearing on the plates were picked off and purified by successive streaking on PY plates. PY stab cultures of the isolates were maintained at $25{ }^{\circ} \mathrm{C}$ under aerobic conditions. Strains $\mathrm{KT}^{\mathrm{T}}$ and $\mathrm{KM} 1^{\mathrm{T}}$, two of the isolates deposited in both the Bioresource Collection and Research Center (BCRC) and the Japan Collection of Microorganisms 
(JCM) as lyophilized cultures, were used for the present study.

Physiological and morphological characterization of strains $\mathrm{KT}^{\mathrm{T}}$ and $\mathrm{KM} 1^{\mathrm{T}}$, including growth and other phenotypic properties, were determined following previously established procedures (Jean et al., 2006). Early stationary phase cells harvested from cultures grown in PY broth or on PY plate medium at $30{ }^{\circ} \mathrm{C}$ for 3 days under aerobic conditions were used for analyses of cellular fatty acids, isoprenoid quinones and DNA base composition according to the methods described by Shieh et al. (2008). However, the HPLC apparatus used for analysis of isoprenoid quinones was equipped with an Inertsil ODS- 2 column $(1.5 \times 250$ $\mathrm{mm}$; GL Science) instead of the Waters model $5 \mathrm{C}_{18}$-AR-II. Fatty acids in whole cells grown on PY plate medium were extracted, saponified and esterified, followed by GC analysis of fatty acid methyl esters according to the MIDI system (Sasser, 2001). The fatty acid methyl ester profile was identified by comparing with the database, 2005 library, supplied in the commercial software package Sherlock
Microbial Identification System version 6.0 (MIDI Inc.). Cells grown in marine agar 2216 (Difco) at $30{ }^{\circ} \mathrm{C}$ for 3 days under aerobic conditions were extracted, purified and analysed for polar lipids according to the methods described by Lin \& Shieh (2006). However, two-dimensional thinlayer chromatograms were developed by using the solvent systems described by Collins \& Jones (1980).

Cells grown in PY broth at $30{ }^{\circ} \mathrm{C}$ for 3 days were harvested by centrifugation. Extraction and purification of total genomic DNA from cells and PCR amplification of 165 rRNA genes were performed according to previously described methods (Jean et al., 2006). Sequencing of $16 \mathrm{~S}$ rRNA genes, multiple alignment and comparison of the resulting sequences with reference sequences available in GenBank, calculation of distance matrices for the aligned sequences, and reconstruction of phylogenetic trees based on the neighbour-joining, maximum-parsimony and maximumlikelihood methods were performed as described by Shieh et al. (2004) and Jean et al. (2006). Robustness of clusters was assessed by a bootstrap analysis of 1000 replications.

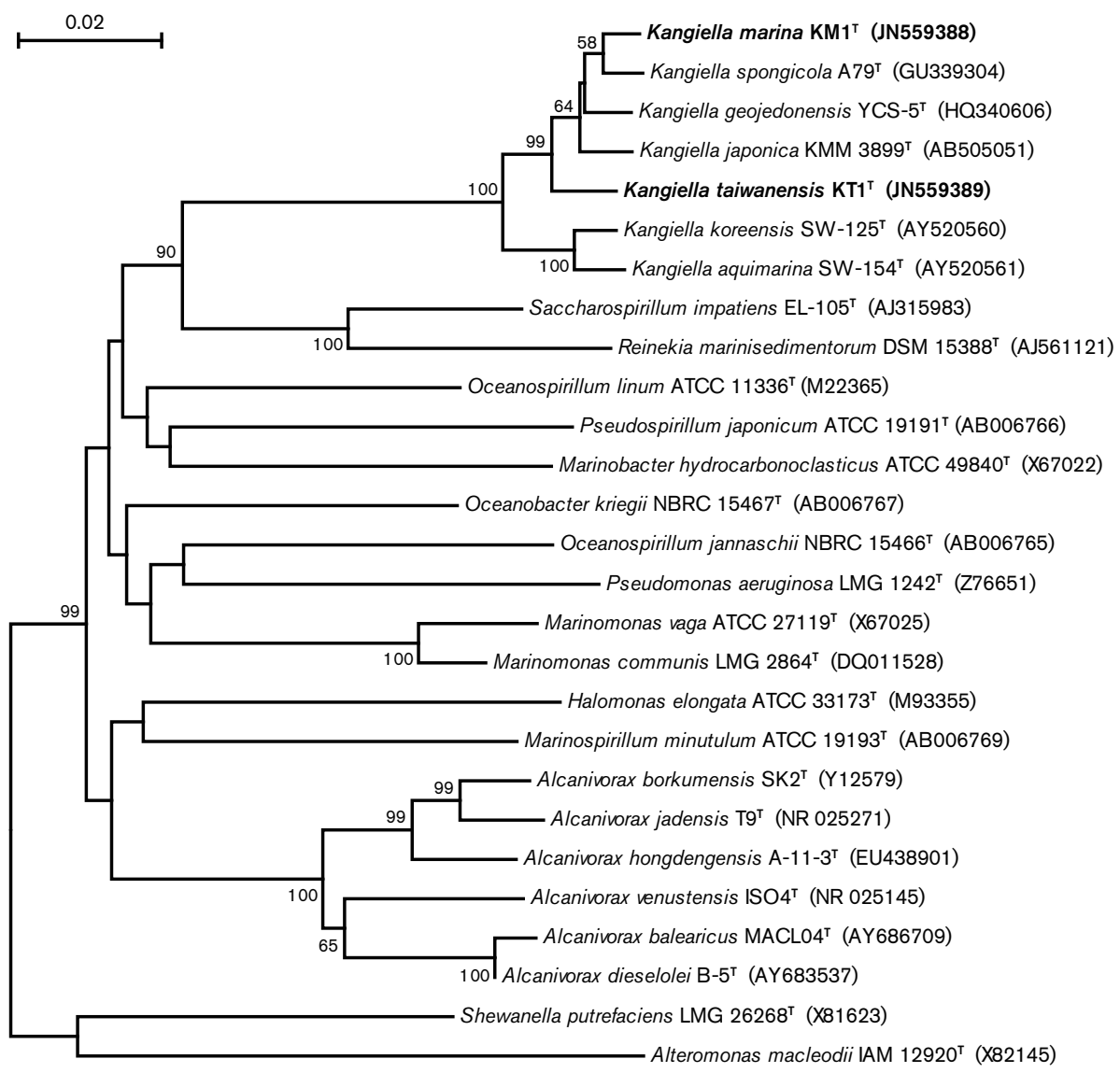

Fig. 1. Neighbour-joining tree showing the phylogenetic relationship between strains $\mathrm{KT} 1^{\top}$ and $\mathrm{KM} 1^{\top}$ and the type strains of recognized species of the genus Kangiella, together with other related taxa belonging to the class Gammaproteobacteria. GenBank accession numbers are given in parentheses. Bootstrap values (percentages of 1000 replicates) $>50 \%$ are shown at branch points. Bar, 2 nt substitutions per 100 nt. 
Nearly complete $16 \mathrm{~S}$ rRNA gene sequences were determined for strains $\mathrm{KT}^{\mathrm{T}}$ (1476 nt) and $\mathrm{KM}^{\mathrm{T}}$ (1490 nt). The two sequences were aligned and compared with those in GenBank. The two sequences shared $98.1 \%$ similarity (28 differences out of $1476 \mathrm{nt}$ positions). These 16S rRNA gene sequences showed the highest levels of similarity to those of the type strains of members of the genus Kangiella (95.6-98.4\%): K. aquimarina (95.6-96.0\%), K. geojedonensis (97.3-98.4\%), K. japonica (97.1-97.8\%), K. koreensis (96.0$96.6 \%)$ and K. spongicola (97.2-98.4\%). No other bacterial species shared more than $90 \% 16 \mathrm{~S}$ rRNA gene sequence similarity with strains $\mathrm{KT}^{\mathrm{T}}$ and $\mathrm{KM} 1^{\mathrm{T}}$. All the above values were lower than the re-evaluated threshold for species differentiation $(98.7 \%)$ as proposed by Stackebrandt \& Ebers (2006). Phylogeny based on a neighbour-joining analysis of $16 \mathrm{~S}$ rRNA gene sequences revealed that strains $\mathrm{KT}^{\mathrm{T}}$ and $\mathrm{KM}^{\mathrm{T}}$ were members of the class Gammaproteobacteria and that they formed a robust cluster (bootstrap value, $100 \%$ ) with their closest neighbours, the type strains of the five recognized Kangiella species (Fig. 1). The cluster could be further divided into two subclusters with bootstrap values of 99 and $100 \%$, respectively. However, relatively low bootstrap values $(<65 \%)$ were observed among the subcluster that consisted of strains $\mathrm{KT}^{\mathrm{T}}$ and $\mathrm{KM}^{\mathrm{T}}$ and the type strains of $K$. geojedonensis, K. japonica and K. spongicola. Similar results were obtained with the maximum-likelihood and maximum-parsimony algorithms (data not shown). The 16S rRNA gene-based phylogeny and sequence similarity data supported the assignment of strains $\mathrm{KT}^{\mathrm{T}}$ and $\mathrm{KM}^{\mathrm{T}}$ to two novel species of Kangiella.

Strains $\mathrm{KT}^{\mathrm{T}}$ and $\mathrm{KM}^{\mathrm{T}}$ contained iso- $\mathrm{C}_{15: 0}$ as the most abundant cellular fatty acid (54.6-57.2\% of the total). Other cellular fatty acids comprising more than $3 \%$ of the total were iso- $\mathrm{C}_{11: 0}(3.8-4.4 \%)$, iso- $\mathrm{C}_{17: 0}(7.2-8.1 \%)$, iso$\mathrm{C}_{17: 1} \omega 9 c(7.5-11.0 \%)$, iso- $\mathrm{C}_{11: 0} 3-\mathrm{OH}(8.4-9.5 \%)$ and summed feature 1 [iso- $\mathrm{C}_{15: 1}$ and/or $\mathrm{C}_{13: 0} 3-\mathrm{OH}$ (the two fatty acids could not be differentiated with the MIDI system); 4.6-6.7\% of the total fatty acids]. The fatty acid profiles were similar among the two isolates and the type strains of Kangiella species, but some qualitative and quantitative differences were observed (Table 1). Although the strains were not cultivated under the same conditions, such differences in the cellular fatty acids might serve to differentiate the two isolates from the type strains of recognized Kangiella species. Q-8 was the only isoprenoid quinone detected in strains $\mathrm{KT}^{\mathrm{T}}$ and $\mathrm{KM} 1^{\mathrm{T}}$. All recognized Kangiella species were also reported as containing Q8 as the predominant isoprenoid quinone. The polar lipids of strain $\mathrm{KT}^{\mathrm{T}}$ consisted of phosphatidylmonomethylethanolamine (major), phosphatidylethanolamine (minor) and two unidentified phospholipids (minor) (Fig. S1 in IJSEM Online). However, the polar lipids of $\mathrm{KM}^{\mathrm{T}}$ comprised three major components, phosphatidylmonomethylethanolamine, phosphatidyldimethylethanolamine and an unidentified phospholipid (Fig. S1). No unidentified amino lipids were detected in the polar lipids of the new isolates
Table 1. Cellular fatty acid contents (\%) of strains $\mathrm{KT}^{\top}{ }^{\top}$ and $\mathrm{KM} 1^{\top}$ and the type strains of recognized species of the genus Kangiella

Strains: $1, \mathrm{KT}^{\mathrm{T}}{ }^{\mathrm{T}}$ (data from this study); $2, \mathrm{KM}^{\mathrm{T}}{ }^{\mathrm{T}}$ (this study); $3, K$. geojedonensis YCS- $5^{\mathrm{T}}$ (Yoon et al., 2012); 4, K. spongicola A79 ${ }^{\mathrm{T}}$ (Ahn et al., 2011); 5, K. japonica KMM $3899^{\mathrm{T}}$ (Romanenko et al., 2010); 6, K. koreensis SW- $125^{\mathrm{T}}$ (Yoon et al., 2004); 7, K. aquimarina SW-154 ${ }^{\mathrm{T}}$ (Yoon et al., 2004). -, Not detected/not reported; tr, trace amount detected $(<1 \%)$.

\begin{tabular}{|c|c|c|c|c|c|c|c|}
\hline Fatty acid & 1 & 2 & 3 & 4 & 5 & 6 & 7 \\
\hline $\mathrm{C}_{14: 0}$ & 1.1 & 1.1 & - & - & - & - & - \\
\hline$C_{16: 0}$ & 1.2 & 2.2 & 3.0 & 4.0 & 3.9 & 1.1 & 1.6 \\
\hline iso- $\mathrm{C}_{11: 0}$ & 4.4 & 3.8 & 6.7 & 7.2 & 4.7 & 5.6 & 6.5 \\
\hline iso- $\mathrm{C}_{13: 0}$ & $\operatorname{tr}$ & 1.1 & $\operatorname{tr}$ & $\operatorname{tr}$ & - & $\operatorname{tr}$ & $\operatorname{tr}$ \\
\hline iso- $\mathrm{C}_{14: 0}$ & $\operatorname{tr}$ & $\operatorname{tr}$ & - & - & - & - & - \\
\hline iso- $\mathrm{C}_{15: 0}$ & 57.2 & 54.6 & 21.4 & 34.9 & 26.9 & 57.6 & 50.7 \\
\hline iso- $\mathrm{C}_{16: 0}$ & 1.5 & $\operatorname{tr}$ & 1.6 & 1.0 & - & $\operatorname{tr}$ & 1.0 \\
\hline iso- $\mathrm{C}_{17: 0}$ & 7.2 & 8.1 & 28.8 & 16.2 & 23.8 & 7.2 & 11.0 \\
\hline anteiso- $\mathrm{C}_{15: 0}$ & $\operatorname{tr}$ & $\operatorname{tr}$ & - & $\operatorname{tr}$ & - & - & - \\
\hline iso- $\mathrm{C}_{15: 1}{ }^{*}$ & 1.0 & 1.7 & $\operatorname{tr}$ & $\operatorname{tr}$ & 6.9 & 1.2 & 1.1 \\
\hline iso- $\mathrm{C}_{17: 1} \omega 9 c$ & 7.5 & 11.0 & 10.9 & 10.5 & 12.7 & 8.6 & 7.0 \\
\hline iso- $\mathrm{C}_{11: 0} 3-\mathrm{OH}$ & 9.5 & 8.4 & 13.0 & 15.4 & 13.6 & 10.5 & 11.7 \\
\hline iso- $\mathrm{C}_{15: 0} 3-\mathrm{OH}$ & - & - & $\operatorname{tr}$ & - & - & $\operatorname{tr}$ & $\operatorname{tr}$ \\
\hline iso- $\mathrm{C}_{17: 0} 3-\mathrm{OH}$ & - & - & 3.4 & 1.6 & - & 1.0 & $\operatorname{tr}$ \\
\hline $\begin{array}{l}\text { Summed } \\
\text { feature } 1 \dagger\end{array}$ & 6.7 & 4.6 & 5.2 & 5.2 & - & 3.2 & 4.0 \\
\hline $\begin{array}{l}\text { Summed } \\
\text { feature } 3 \dagger\end{array}$ & $\operatorname{tr}$ & 1.1 & $\operatorname{tr}$ & 1.9 & - & - & - \\
\hline
\end{tabular}

${ }^{\star}$ The double bond position is unknown.

$\dagger$ Summed features represent groups of two fatty acids that cannot be separated by GLC with the MIDI system. Summed feature 1 comprised iso- $\mathrm{C}_{15: 1}$ and/or $\mathrm{C}_{13: 0} 3-\mathrm{OH}$; summed feature 3 comprised $\mathrm{C}_{16: 1} \omega 7 c$ and/or iso- $\mathrm{C}_{15: 0} 2-\mathrm{OH}$.

when the analysis was performed by using ninhydrin as the staining reagent. Phosphatidylglycerol was found as one of the major phospholipids in both $K$. koreensis and $K$. geojedonensis. However, this phospholipid was not detected in

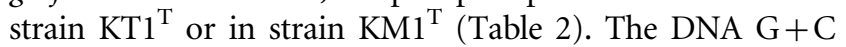
contents of strains $\mathrm{KT}^{\mathrm{T}}(43.9 \mathrm{~mol} \%)$ and $\mathrm{KM}^{\mathrm{T}}(46.3$ mol\%) fell roughly within the range of values reported for recognized Kangiella species (44.0-47.0 mol\%) (Table 2).

Strains $\mathrm{KT}^{\mathrm{T}}$ and $\mathrm{KM} 1^{\mathrm{T}}$ were mesophilic, halophilic, nonmotile and Gram-negative. They produced circular, convex, light brown, opaque and non-luminescent colonies with entire edges. Cells of the strains grown in PY broth appeared to be straight and non-flagellated as revealed by transmission electron microscopy (not shown). The two strains were capable of anaerobic growth by nitrate reduction to nitrite but not by fermentation of D-glucose or other carbohydrates such as D-arabinose, L-arabinose, cellobiose, D-galactose, lactose, D-mannose, melibiose, sucrose, trehalose and D-xylose as substrates. 
Table 2. Differential characteristics between strains $\mathrm{KT} 1^{\top}$ and $\mathrm{KM} 1^{\top}$ and the type strains of recognized species of the genus Kangiella

Strains: $1, \mathrm{KT}^{\mathrm{T}}$ (data from this study); 2, $\mathrm{KM}^{\mathrm{T}}$ (this study); 3, K. geojedonensis YCS-5 ${ }^{\mathrm{T}}$ (Yoon et al., 2012); 4, K. spongicola A79 ${ }^{\mathrm{T}}$ (Ahn et al., 2011); 5, K. japonica KMM $3899^{\mathrm{T}}$ (Romanenko et al., 2010); 6, K. koreensis SW-125 $5^{\mathrm{T}}$ (Yoon et al., 2004); 7, K. aquimarina SW-154 ${ }^{\mathrm{T}}$ (Yoon et al., 2004). W, Weakly positive; ND, no data available.

\begin{tabular}{|c|c|c|c|c|c|c|c|}
\hline Characteristic & 1 & 2 & 3 & 4 & 5 & 6 & 7 \\
\hline Nitrate reduction & + & + & - & + & - & + & + \\
\hline Anaerobic growth & + & + & - & + & - & + & + \\
\hline Acid production from D-glucose & - & - & - & - & + & - & - \\
\hline \multicolumn{8}{|l|}{ Hydrolysis of: } \\
\hline Casein & - & + & + & + & + & + & + \\
\hline Gelatin & + & + & + & - & + & + & + \\
\hline Tween 80 & + & - & + & + & + & + & + \\
\hline \multicolumn{8}{|l|}{ Growth at/with: } \\
\hline $10{ }^{\circ} \mathrm{C}$ & - & - & + & + & + & + & + \\
\hline $42{ }^{\circ} \mathrm{C}$ & - & - & ND & + & + & + & + \\
\hline $45^{\circ} \mathrm{C}$ & - & - & - & + & - & - & + \\
\hline $15 \% \mathrm{NaCl}$ & - & - & + & + & - & - & - \\
\hline Temperature optimum $\left({ }^{\circ} \mathrm{C}\right)$ & $25-30$ & $25-30$ & 30 & $10-49$ & $28-35$ & $30-37$ & $30-37$ \\
\hline $\mathrm{NaCl}$ optimum (\%) & $2-5$ & $2-5$ & 2 & $2-10$ & $2-3$ & $2-3$ & $2-3$ \\
\hline \multicolumn{8}{|l|}{ API ZYM results } \\
\hline Alkaline phosphatase & - & + & + & + & - & + & + \\
\hline Valine arylamidase & + & + & - & + & + & + & + \\
\hline Cystine arylamidase & + & + & - & - & - & - & - \\
\hline Trypsin & + & $\mathrm{w}$ & - & - & - & + & + \\
\hline$\alpha$-Chymotrypsin & + & $\mathrm{w}$ & - & + & - & - & - \\
\hline Acid phosphatase & - & - & + & + & - & - & + \\
\hline Naphthol-AS-BI-phosphohydrolase & - & - & + & + & $\mathrm{w}$ & + & + \\
\hline \multicolumn{8}{|l|}{ Polar lipids ${ }^{*}$} \\
\hline Major & PME & PME, $\mathrm{PDE}, \mathrm{PL}_{3}$ & PG, AL & $\mathrm{ND}$ & ND & PG, PME, PE, AL & $\mathrm{ND}$ \\
\hline Minor & $\mathrm{PE}, \mathrm{PL}_{1}, \mathrm{PL}_{2}$ & & PME, PE & $\mathrm{ND}$ & $\mathrm{ND}$ & & ND \\
\hline DNA G $+\mathrm{C}$ content $(\mathrm{mol} \%)$ & 43.9 & 46.3 & 47.0 & 44.9 & 45.8 & 44.0 & 44.0 \\
\hline
\end{tabular}

^PME, phosphatidylmonomethylethanolamine; PE, phosphatidylethanolamine; PG, phosphatidylglycerol; PDE, phosphatidyldimethylethanolamine; $\mathrm{PL}_{1}, \mathrm{PL}_{2}$ and $\mathrm{PL}_{3}$, three different unidentified phospholipids; $\mathrm{AL}$, an unidentified aminolipid. Data for the polar lipids of $K$. geojedonensis $\mathrm{YCS}-5^{\mathrm{T}}$ and K. koreensis $\mathrm{SW}-125^{\mathrm{T}}$ are from Yoon et al. (2012).

Strains $\mathrm{KT}^{\mathrm{T}}$ and $\mathrm{KM}^{\mathrm{T}}$ shared many physiological and morphological characteristics. However, they could be differentiated from each other based on different reactions in tests for hydrolysis of casein and Tween 80 and activity of alkaline phosphatase, $\alpha$-chymotrypsin and trypsin. The two strains could be distinguished from recognized Kangiella species based on the inability to grow at $10{ }^{\circ} \mathrm{C}$, and presence of cystine arylamidase and absence of naphthol-AS-BI-phosphohydrolase in API ZYM tests. Additional characteristics useful for differentiating strains $\mathrm{KT} 1^{\mathrm{T}}$ and $\mathrm{KM} 1^{\mathrm{T}}$ from recognized Kangiella species are given in Table 2.

The polyphasic data from this study support the establishment of two novel Kangiella species to accommodate strains $\mathrm{KT}^{\mathrm{T}}$ and $\mathrm{KM}^{\mathrm{T}}$, for which the names Kangiella taiwanensis sp. nov. and Kangiella marina sp. nov. are proposed, respectively.

\section{Description of Kangiella taiwanensis sp. nov.}

Kangiella taiwanensis (tai.wan.en'sis. N.L. fem. adj. taiwanensis pertaining to Taiwan, where the type strain was isolated).

Cells are non-motile, Gram-negative rods, 1.5-2.0 $\mu \mathrm{m}$ long and $0.5-1.0 \mu \mathrm{m}$ wide. Colonies produced on PY plate medium at $30{ }^{\circ} \mathrm{C}$ for $3-7$ days are circular (approx. 2$6 \mathrm{~mm}$ in diameter), light brown, opaque, convex and nonluminescent, with entire edges. Endospores are absent. Growth occurs at $15-40{ }^{\circ} \mathrm{C}$, with optimum growth at 25 $30{ }^{\circ} \mathrm{C}$; no growth occurs at $4-10$ or $42-45{ }^{\circ} \mathrm{C}$. Sodium ions are required for growth; growth occurs in the presence of $0.5-12 \%(\mathrm{w} / \mathrm{v}) \mathrm{NaCl}$, with optimum growth at $2-5 \%$, and no growth at 0 or $15 \% \mathrm{NaCl}$. Grows at $\mathrm{pH} 7-10$, but not at $\mathrm{pH} 5-6$. Anaerobic growth occurs by nitrate reduction (to nitrite) but not by fermentation of D-glucose or other 
carbohydrates as substrates. Oxidase- and catalase-positive. Indole is not produced from tryptophan. $\mathrm{H}_{2} \mathrm{~S}$ is not produced from thiosulfate. Hydrolyses gelatin, lecithin and Tween 80 , but not aesculin, casein, chitin, DNA, starch or urea. In assays with the API ZYM system (bioMérieux), positive for cystine arylamidase, leucine arylamidase, valine arylamidase, esterase (C4), esterase lipase (C8), $\alpha$-chymotrypsin and trypsin, but negative for $\alpha$-fucosidase, $\alpha$ galactosidase, $\beta$-galactosidase, $\alpha$-glucosidase, $\beta$-glucosidase, $\beta$-glucuronidase, $\alpha$-mannosidase, lipase (C14), acid phosphatase, alkaline phosphatase, $N$-acetyl- $\beta$-glucosaminidase and naphthol-AS-BI-phosphohydrolase. Acid production is not observed with oxidation or fermentation of single carbon sources provided by the API $50 \mathrm{CH}$ system (bioMérieux) and Biolog GN2 microplates. Susceptible to ampicillin $(10 \mu \mathrm{g})$, cephalothin $(30 \mu \mathrm{g})$, chloramphenicol $(30 \mu \mathrm{g})$, colistin $(10 \mu \mathrm{g})$, erythromycin $(15 \mu \mathrm{g})$, nalidixic acid $(30 \mu \mathrm{g})$ and polymyxin B (300 $\mathrm{U})$, and intermediately susceptible to penicillin $\mathrm{G}(10 \mathrm{U})$. Resistant to gentamicin $(10 \mu \mathrm{g})$, kanamycin $(30 \mu \mathrm{g})$, neomycin $(30 \mu \mathrm{g})$, oxacillin $(1 \mu \mathrm{g})$, streptomycin $(10 \mu \mathrm{g})$, tetracycline $(30 \mu \mathrm{g})$ and vancomycin $(30 \mu \mathrm{g})$. Q-8 is the only isoprenoid quinone. Phosphatidylmonomethylethanolamine is the major polar lipid. Major cellular fatty acids $(>1 \%)$ are iso- $\mathrm{C}_{15: 0}$, iso$\mathrm{C}_{11: 0} 3-\mathrm{OH}, \mathrm{C}_{17: 1} \omega 9 c$, iso- $\mathrm{C}_{17: 0}$, summed feature 1 (iso$\mathrm{C}_{15: 1}$ and/or $\mathrm{C}_{13: 0}$ 3-OH), iso- $\mathrm{C}_{11: 0}, \mathrm{C}_{14: 0}, \mathrm{C}_{16: 0}$, iso- $\mathrm{C}_{16: 0}$ and iso- $\mathrm{C}_{15: 1}$.

The type strain, $\mathrm{KT}^{\mathrm{T}}\left(=\mathrm{BCRC} 80330^{\mathrm{T}}=\mathrm{JCM} 17727^{\mathrm{T}}\right)$, was isolated from shallow coastal seawater of Bangbang, New Taipei City, Taiwan. The DNA G + C content of the type strain is $43.9 \mathrm{~mol} \%$.

\section{Description of Kangiella marina sp. nov.}

Kangiella marina (ma.ri'na. L. fem. adj. marina of the sea, marine).

Cells are non-motile, Gram-negative rods, $0.7-1.2 \mu \mathrm{m}$ long and $0.3-0.5 \mu \mathrm{m}$ wide. Colonies produced on PY plate medium at $30{ }^{\circ} \mathrm{C}$ for $3-7$ days are circular (approx. 1$4 \mathrm{~mm}$ in diameter), light brown, opaque, convex and nonluminescent, with entire edges. Endospores are absent. Growth occurs at $15-40{ }^{\circ} \mathrm{C}$, with optimum growth at 25 $30{ }^{\circ} \mathrm{C}$; no growth occurs at $4-10$ or $42-45{ }^{\circ} \mathrm{C}$. Sodium ions are required for growth; growth occurs in the presence of $1-8 \%(\mathrm{w} / \mathrm{v}) \mathrm{NaCl}$, with optimum growth at $2-5 \%$, and no growth at 0 or $15 \% \mathrm{NaCl}$. Grows at $\mathrm{pH} 7-9$, but not at $\mathrm{pH}$ 5-6. Anaerobic growth occurs by reduction of nitrate to nitrite but not by fermentation of D-glucose or other carbohydrates as substrates. Oxidase- and catalase-positive. Indole is not produced from tryptophan. $\mathrm{H}_{2} \mathrm{~S}$ is not produced from thiosulfate. Hydrolyses casein, gelatin and lecithin (weakly positive), but not aesculin, chitin, DNA, starch, Tween 80 or urea. In assays with the API ZYM system (bioMérieux), positive for cystine arylamidase, leucine arylamidase, valine arylamidase, esterase (C4), esterase lipase (C8), $\alpha$-chymotrypsin (weakly), alkaline phosphatase and trypsin (weakly), but negative for $\alpha$-fucosidase, $\alpha$-galactosidase, $\beta$-galactosidase, $\alpha$-glucosidase, $\beta$-glucosidase, $\beta$-glucuronidase, $\alpha$-mannosidase, lipase (C14), acid phosphatase, alkaline phosphatase, $N$-acetyl- $\beta$-glucosaminidase and naphthol-AS-BI-phosphohydrolase. Acid production is not observed with oxidation or fermentation of single carbon sources provided by the API $50 \mathrm{CH}$ system (bioMérieux) and Biolog GN2 microplates. Susceptible to ampicillin $(10 \mu \mathrm{g})$, cephalothin $(30 \mu \mathrm{g})$, chloramphenicol $(30 \mu \mathrm{g})$, colistin $(10 \mu \mathrm{g})$, erythromycin $(15 \mu \mathrm{g})$, nalidixic acid $(30 \mu \mathrm{g})$ and polymyxin B $(300 \mathrm{U})$, and intermediately susceptible to penicillin $\mathrm{G}(10 \mathrm{U})$. Resistant to gentamicin $(10 \mu \mathrm{g})$, kanamycin $(30 \mu \mathrm{g})$, neomycin $(30 \mu \mathrm{g})$, oxacillin $(1 \mu \mathrm{g})$, streptomycin $(10 \mu \mathrm{g})$, tetracycline $(30 \mu \mathrm{g})$ and vancomycin $(30 \mu \mathrm{g})$. Q-8 is the only isoprenoid quinone. Major polar lipids are phosphatidylmonomethylethanolamine, phosphatidyldimethylethanolamine and an unidentified phospholipid. Major cellular fatty acids $(>1 \%)$ are iso- $\mathrm{C}_{15: 0}, \mathrm{C}_{17: 1} \omega 9 c$, iso- $\mathrm{C}_{11: 0} 3-\mathrm{OH}$, iso- $\mathrm{C}_{17: 0}$, summed feature 1 (iso- $\mathrm{C}_{15: 1}$ and/or $\mathrm{C}_{13: 0} 3-\mathrm{OH}$ ), iso- $\mathrm{C}_{11: 0}, \mathrm{C}_{14: 0}$, $\mathrm{C}_{16: 0}$, iso- $\mathrm{C}_{13: 0}$, iso- $\mathrm{C}_{15: 1}$ and summed feature 3 (iso$\mathrm{C}_{16: 1} \omega 7 c$ and/or iso- $\left.\mathrm{C}_{15: 0} 2-\mathrm{OH}\right)$.

The type strain, $\mathrm{KM}^{\mathrm{T}}\left(=\mathrm{BCRC} 80329^{\mathrm{T}}=\mathrm{JCM} 17728^{\mathrm{T}}\right)$, was isolated from shallow coastal seawater of Shenao, New Taipei City, Taiwan. The DNA G + C content of the type strain is $46.3 \mathrm{~mol} \%$.

\section{Acknowledgements}

This study was supported by the National Science Council, Taiwan (grants NSC96-2628-E-426-001, NSC98-2221-E-426-003, NSC982313-B-002-057-MY2 and NSC100-2611 M-002-011).

\section{References}

Ahn, J., Park, J.-W., McConnell, J. A., Ahn, Y.-B. \& Häggblom, M. M. (2011). Kangiella spongicola sp. nov., a halophilic marine bacterium isolated from the sponge Chondrilla nucula. Int J Syst Evol Microbiol 61, 961-964.

Collins, M. D. \& Jones, D. (1980). Lipids in the classification and identification of coryneform bacteria containing peptidoglycans based on 2,4-diaminobutyric acid. J Appl Bacteriol 48, 459-470.

Jean, W. D., Shieh, W. Y. \& Chiu, H.-H. (2006). Pseudidiomarina taiwanensis gen. nov., sp. nov., a marine bacterium isolated from shallow coastal water of An-Ping Harbour, Taiwan, and emended description of the family Idiomarinaceae. Int J Syst Evol Microbiol 56, 899-905.

Lin, Y.-T. \& Shieh, W. Y. (2006). Zobellella denitrificans gen. nov., sp. nov. and Zobellella taiwanensis sp. nov., denitrifying bacteria capable of fermentative metabolism. Int J Syst Evol Microbiol 56, 1209-1215.

Romanenko, L. A., Tanaka, N., Frolova, G. M. \& Mikhailov, V. V. (2010). Kangiella japonica sp. nov., isolated from a marine environment. Int J Syst Evol Microbiol 60, 2583-2586.

Sasser, M. (2001). Identification of bacteria by gas chromatography of cellular fatty acids, Technical note 101. Newark, DE: MIDI Inc.

Shieh, W. Y., Chen, A.-L. \& Chiu, H.-H. (2000). Vibrio aerogenes sp. nov., a facultatively anaerobic marine bacterium that ferments glucose with gas production. Int J Syst Evol Microbiol 50, 321-329. 
Shieh, W. Y., Lin, Y.-T. \& Jean, W. D. (2004). Pseudovibrio denitrificans gen. nov., sp. nov., a marine, facultatively anaerobic, fermentative bacterium capable of denitrification. Int J Syst Evol Microbiol 54, $2307-2312$

Shieh, W. Y., Liu, T. Y., Lin, S. Y., Jean, W. D. \& Chen, J.-S. (2008). Simiduia agarivorans gen. nov., sp. nov., a marine, agarolytic bacterium isolated from shallow coastal water from Keelung, Taiwan. Int J Syst Evol Microbiol 58, 895-900.
Stackebrandt, E. \& Ebers, J. (2006). Taxonomic parameters revisited: tarnished gold standards. Microbiol Today 33, 152-155.

Yoon, J. H., Oh, T. K. \& Park, Y. H. (2004). Kangiella koreensis gen. nov., sp. nov. and Kangiella aquimarina sp. nov., isolated from a tidal flat of the Yellow Sea in Korea. Int J Syst Evol Microbiol 54, 1829-1835.

Yoon, J. H., Kang, S.-J., Lee, S.-Y., Lee, J.-S. \& Oh, T.-K. (2012). Kangiella geojedonensis sp. nov., isolated from seawater. Int J Syst Evol Microbiol 62, 511-514. 